https://doi.org/10.4316/CC.2020.02.002

SOCIETY, ELITES, CONFLICTS

\title{
LANDMARKS OF THE VIRAL-METAMORPHIC THEORY. A NEW INTERPRETATION OF RIGHT-WING TOTALITARIANISM (I)
}

\author{
Vlad GAFIT,A \\ Stefan cel Mare University of Suceava (Romania) \\ E-mail: vladgafita@usm.ro
}

\begin{abstract}
The viral-metamorphic theory offers a new way of interpreting right-wing totalitarianism, in the context in which not even a single vision of this phenomenon has yet been achieved. Although the definitions of generic fascism, regarded as Ideal-type, are incredibly numerous and diverse, there is no unanimous opinion about its true nature. The path we chose is circumscribed by the comparative analysis of this type of totalitarianism's ideational origins, returning thus to its theoretical, philosophical and political foundations. We do not claim by any means to fully solve such a vast problem-and, if we did, of course, we would leave the sphere of historical reality and enter a world of fantasy, speculation and utopia. Within the bounds of our intellectual and spiritual possibilities, we have designed a new model of analysis of the interwar far-right, which we have called viral-metamorphic, appropriating and adapting concepts from geology (metamorphism), biology and computer science (virus/viral), along with the wide synonymic range of the above-mentioned terms.
\end{abstract}

Keywords: metamorphic, theory, right-wing totalitarianism, comparative analysis, fascism, ideal type, viral.

Rezumat. Repere ale teoriei viral-metamorfice. $O$ nouă interpretare a totalitarismului de dreapta (I). Prin teoria viral-metamorfică, încercăm să oferim o nouă modalitate de interpretare a totalitarismului de dreapta, în condițiile în care, nici măcar până în prezent, nu s-a ajuns la o viziune unitară asupra acestui fenomen. Deși definițiile fascismului generic, privit ca ideal-tip, sunt extrem de numeroase și diverse, nu s-a ajuns la o părere unanimă asupra adevăratei sale naturi. Calea aleasă de noi se circumscrie analizei comparative a originilor ideatice ale acestui tip de totalitarism, întorcându-ne așadar la bazele sale teoretice, filosofice și politice. Nu avem pretenția că vom reuși să lămurim în totalitate o problematică atât de vastă - iar, dacă am face-o, desigur că am părăsi sfera realității istorice și am pătrunde într-o lume a fanteziei, speculației și utopiei. În limitele posibilităților noastre intelectuale și spirituale, am creat un model nou de analiză al extremei drepte interbelice, pe care l-am numit viral-metamorfic, preluând și adaptând concepte din geologie (metamorfism),

Copyright (C) 2020 “Codrul Cosminului”, XXVI, 2020, No. 2, p. 303-330. 
biologie și informatică (virus/viral), precum și larga sinonimie a termenilor mai sus amintiți. În prezent, cuvântul metamorfism are reverberații cu precădere în domeniul științelor Pământului (geografie, geologie, geochimie ș.a.), desemnând transformarea în stare solidă a rocilor (mineralogică, chimică și structurală) sub influența căldurii (metamorfism de contact termic), a presiunii (m. dinamic), a soluțiilor metamorfozante (metamorfism metasomatic) sau acțiunii combinate a presiunii și temperaturii (metamorfism dinamometric sau regional); după astfel de procese iau naștere rocile metamorfice.

\section{INTRODUCTION}

The proposed new interpretation of right-wing totalitarianism attempts to provide a holistic and integrative view of the variations of the ideological, political, social and economic fascist phenomenon. The far-right lacks the ideological cohesion that communism enjoys, manifesting itself as a trans ideology, which tends to become an independent ideology, parasitising older political currents, which it transforms or destroys. The concept of viral metamorphism has been chosen because of this fact. Initially, the use of the term was made with strict reference to the sphere of ideology. ${ }^{1}$ It has been observed that the fascist Ideal type acquires a metamorphic character when it comes into contact with established ideologies (liberalism, conservatism, ${ }^{2}$ socialism, communism), i.e., it shows a tendency to

${ }^{1}$ About the conceptual sphere of ideology, see: Terry Eagleton, Ideology: An Introduction, Londra-New York, Versus, 1991; Teun A. Van Dijk, Ideology. A Multidisciplinary Approach, Londra - Thousand Oaks - New Delhi, SAGE Publications, 1998; Daniel Șandru, Reinventarea ideologiei. O abordare teoretico-politică [Reinventing ideology. A Theoretical-political Approach], Iași, European Institute, 2009.

${ }^{2}$ Joseph de Maistre, Essai sur le principe générateur des constitutions politiques et des autres insitututions humaines, Paris, Les Belles Lettres, 1833, p. 3; Anton Carpinschi, Conservatorismul, doctrină a autorităţii şi restauraţiei [Conservatism, the doctrine of authority and restoration], in Alina Mungiu-Pippidi (coord.), Doctrine politice contemporane. Tipologii, dinamică, perspective [Contemporary political doctrines. Typologies, dynamics, perspectives] Iaşi, Moldova Publishing House, 1992; Adrian-Paul Iliescu, Conservatorismul anglo-saxon [Anglo-Saxon Conservatism], Bucharest, All Publishing House, 1994; idem, Conservatorismul [Conservatism], in Alina Mungiu-Pippidi (coord.), Doctrine politice contemporane. Tipologii, dinamică, perspective [Contemporary political doctrines. Typologies, dynamics, perspectives], Iaşi, Moldova Publishing House, 1992; Robert Nisbet, Conservatorismul [Conservatism] Bucharest, Du Style Publishing House, 1998; Norberto Bobbio, Stânga şi dreapta [Left and Right], Bucharest, Humanitas Publishing House, 1999; Joseph de Maistre, Istorie şi providenţă [History and Prov- 
transform or destroy them, or takes over some of their features, which it alters most of the times; at the same time, it self-replicates, thus becoming a mutant ideological entity.

Currently, the term virus has at least three meanings: biological - pathogen, invisible to the naked eye, which multiplies only inside living cells and causes various infectious diseases; figurative - agent of contagion, source of moral evil; computer - a computer program that can self-replicate, intended to disrupt computer functions. The word virus also has a relatively diverse synonymy: destructive factor, disease, misfortune, infection, condition, contagion, contamination, corruption, defilement etc. Its derivative (viral) refers to something that can infect or infest a being, an object, a process or a phenomenon. Starting from the definition of the virus from a biological point of view (a nonautonomous pathogenic organism that multiplies into the DNA of other creatures, which it infects) - it has become clear that the ideology of the far-right behaves somewhat similarly to the classical ideologies of modernity.

Analysing the lack of conceptual autonomy of generic fascism (the fascist minimum - that is, all standard features of fascism, Nazism, and other resembling European fascist movements), and trying to answer the fundamental question: Is this a self-contained ideology or not? - a seemingly strange and contradictory conclusion emerges: It is not an entity similar to other ideological systems, but rather a new type of ideology, characterised by viral metamorphism. Furthermore, by investigating the conceptual and theoretical meanings and implications of ideology in general, one can find that right-wing totalitarianism is indeed a system of beliefs, but not a coherent and consolidated axiological (value-related) system.

idence], Bucharest, Anastasia Publishing House, 1997; Noel O'Sullivan, Conservatorismul [Conservatism], in Enciclopedia Blackwell a gândirii politice [The Blackwell Encyclopaedia of Political Thought], Bucharest, Humanitas Publishing House, 2000; Daniel Louis Seiler, Partidele politice din Europa [Political parties in Europe], Iași, European Institute Publishing House, 1999; Sorin Bocancea, Conservatorismul [Conservatism], in Eugen Huzum (coord.), Teorii politice și ideologii [Political theories and ideologies], Iași European Institute Publishing House, 2013; Mihai Zodian, Conservatorismul [Conservatism], in Mihaela Miroiu (coord.), Ideologii politice actuale. Semnificații, evoluții, și impact [Current political ideologies. Meanings, evolutions and impact], Iași, Polirom Publishing House, 2012; Antoine Compagnon, Antimodernii. De la Joseph de Maistre la Roland Barthes [Anti-moderns. From Joseph de Maistre to Roland Barthes], translation from French by Irina Mavrodin and Adina Dinițoiu, Bucharest, Art Publishing House, 2008, pp. 12-48. 
Unlike fascism, left-wing totalitarianism has robust universalist features, which gives it greater ideological and doctrinal continuity.

Having decided to critically examine the dogmatic assertion that totalitarianism is the opposite of democracy, and aiming for a considerate answer one must first turn towards the origins and multiple meanings of the political regime defined as the people's power. It became evident that the two systems of government are devoted to the same goal - the Demos' good; it is, therefore, a different view of the same problem. As such, the preliminary conclusion is that both types of totalitarianism (left and right) derive and are not the opposite of democracy; they are revealed to us, therefore, only as mutations of democracy. Along with the logical-explanatory approach of viral metamorphism, it turns out that a fundamental role in the birth and ideological development of the far right was played by "infecting pluralistic political thought" with an irrational mentality (consisting of existentialism, intuitionism, vitalism, nihilism, symbolism, and the restoration of magical, archetypal, mystical, mythical, and taboo thinking).

One of the most challenging issues that this study has attempted, at least partially, to solve, is the relationship between totalitarianism and modernity, based on the political and social principles of the Enlightenment. The reaction to the Enlightenment philosophy and the liberal model of government led to the "premature birth" of a dimorphic organism (with the ability to take two forms/ shapes). Communism was according to the one-dimensional theory of political parties - on the far left of the political spectrum, while fascism/ Nazism and fascist movements were positioned to the far right. Although we formally accept this classification, one must recall its relative nature. It would seem that fascism and Nazism were, in fact, only transmutations (transubstantiations) of socialism, produced under the particular conditions of redefining Italian and German nationalisms, respectively, after World War One. The two movements called themselves "the third way", so they did not want to be associated with either the left or the right. Both communism and generic fascism were characterised by intense polymorphism.

The term has mainly three directions of definition: chemical - the property of certain substances to be able to appear in two or more distinct crystalline forms; biological - the characteristic of a species to exist in several morphological aspects; philological - the coexistence of numerous forms, phonetic or grammatical, with the same function in the system, in a particular language or idiom. This study will refer to it concerning its synonymy. Thus, polymorphism can also mean diversity, diversification, heterogeneity, multiform, multiplicity, variation, variety, variability, multitude, conglomerate, fluctuation, dissonance, mixture, miscellaneous, 
multilateralism etc. This article will use it in connection with the following fields: ideological, political, social, economic, cultural, anthropological etc.

Despite the doctrinal consistency offered by Karl Marx, Friedrich Engels, Vladimir Ilich Lenin, Leon Trotsky, etc., Bolshevism has retained its polymorphic features. Although it calls itself an evolved and superior democracy, the negationist relationship of left-wing totalitarianism with liberal political principles (equality, liberty, individualism, social contractualism, etc.) shows its true despotic nature ("dictatorship of the proletariat" masked by populism, terror "motivated" by the "class struggle", "the creation of a new man" or an egalitarian and better society).

Due to the absence of universalism, right-wing totalitarianism is characterised by a more pronounced polymorphism than communism, taking the most varied and paradoxical forms. It often appears as revolutionary, extreme and radical conservatism. It is not by accident that fascism was metaphorically called a conservative revolution, a reactionary process, or a militant reaction. Consequently, this suggests that a comparative analysis of the two ideological trends would be more than welcome, given that most researchers claim that the far right was anti-conservative in the interwar period.

\section{RIGHT-WING TOTALITARIANISM AS A "CONSERVATIVE REVOLUTION"}

Both conservatives and fascists have adopted a fundamentally pessimistic view of human nature, considering it fallible, imperfect and corruptible. Although the former accepted the idea that emotions, impulses, instincts often drive man, they did not give the same importance to irrational influences on human behaviour. Although many of the representatives and followers of conservative thinking have been influenced by racial or anti-Semitic prejudices, nowadays politicians of this ideological standing reject these concepts, labelling them as undemocratic and anti-humanist. The two sides agree that genetic and hereditary backgrounds generate natural differences in talent and abilities, meaning that some individuals would be better suited than others for political leadership.

Both the conservative and the extremist right-wing ideology have traditionally been strongly nationalist. For example, Benjamin Disraeli argued that it was essential to promote national unity as a means of securing the economic progress and imperial expansion of Great Britain. He believed that by importing cheap raw materials, the average living standard would improve considerably, including for lower social classes. At the same time, he wanted to 
undermine the rise of socialism through a series of reform policies, "orchestrated" by the conservatives themselves. ${ }^{3}$ In practice, however, the European imperialist expansion at the end of the 19th century was achieved rather by force of arms. This attitude was embraced completely by Nazism and, to a lesser extent, by Mussolini's Italy. Militarism was accepted and supported by both Italian and German nationalist conservatives, though not with the same intensity of fascist and, respectively, national-socialist brutality. The conservative view of human nature has led followers to support economic inequality, especially in terms of income distribution and wealth. Thus, genetic differences in talent and skills ought to result in wealth inequality, at least if the government does not restrict the freedom of individuals to convert their talent into economic advantage. Therefore, in keeping with the conservative view, economic equality is incompatible with individual equality. ${ }^{4}$ Right-wing totalitarianism extended the principle of inequality across society, 5 its hierarchy being made according to the model of castes (closed and self-sufficient social categories).

Conservatism aims to build a fairer history and society, relying on traditions and customs. The far-right prefers to exploit history, traditions, customs, and social habits to create a closed, hierarchical, statist and racist society. At the top of such a structure are the people who limit attributions and control the state's functioning. In contrast, at the bottom of it, there are massed individuals totally subordinated to it. Conservative thinking states that the people's welfare can only be achieved by maintaining the traditions, customs and social habits established throughout history. ${ }^{6}$ Generic fascism is grounded in exploiting the elements outlined above, not in the Demos' best interest, but in that of the new totalitarian

${ }^{3}$ Regarding the conservative vision of Benjamin Disraeli, see: Angus Hawkins, Disraeli and Conservatism, 1874-1880, in British Party Politics, 1852-1886, London, Palgrave, 1998, pp. 178-190.

${ }^{4}$ Roger Woods, The Conservative Revolution in the Weimar Republic, London, Macmillan Press Ltd., 1996, pp. 111-115.

${ }^{5}$ Dante Germino, Preliminary Reflections on the Open Society: Bergson, Popper, Voegelin, in Dante Germino, Klaus von Beyme (eds.), The Open Society in Theory and Practice, Haga, Martinus Nijhoff, 1974, pp. 1 - 4; Eric Voegelin, Order and History, vol. II, The World of the Polis, Baton Rouge, Louisiana State University Press, 1957, pp. 1 - 5; K. R. Popper, Societatea deschisă şi duşmanii ei [The Open Society and Its Enemies], vol. I, Vraja lui Platon [The Spell of Plato], translated into Romanian by D. Stoianovici, Bucharest, Humanitas Publishing House, 2005, pp. 121-126.

${ }^{6}$ Russel Kirk, The Conservative Mind: From Burke to Eliot, Revised Edition, Chicago, Henry Regnery Company, 1960, pp. 2-9. 
elite. For followers of conservatism, observing the principles of the past is equivalent to creating the social good. In their view, this is because we already know that these rules work and, as such, we cannot guarantee the efficiency of new ideas. The fascist oligarchy interprets in its way the principles of the past, their vision gaining the value of absolute truth; it conveys to the obedient masses what can or cannot be preserved from these "immutable" rules of the past. People must be told what is right for them by the conservative government, and in the case of the far-right, by the fascist leaders. Generally, conservatism is regarded as a paternalistic theory, whereas fascism is considered a messianic theory, mainly because of its political religion nature.

Conservative political theory maintains that the government always has better ideas than private individuals; right-wing totalitarianism leaves no room for interpretation by proclaiming that the Leader can never err. Conservatives embrace the idea that governments are only useful as long as they promote loyalty to history, traditions and customs because they are superior forms of individual thinking. Manipulated knowledge of history is apparently superior to independent thinking as it derives from the fascist totalitarian elite's mindset. The conservative political trend has regularly theorised the inferiority of individual thought concerning the wisdom of historical generations. In contrast, the far-right independent thinking loses its validity because the fascist elite interprets the wisdom accrued by generations following the world's utopian vision. Thus, conservatives consider knowledge acquired through the ages to be more reliable and closer to the truth than individuals' mere accumulation of knowledge. Hence, it has to go through the difficult test of time. The cognisable domain has no intrinsic value unless it is "validated" by the intensely ideologized totalitarian elite. Conservative ideology states that people should be aware of their limitations and admit that they cannot, by themselves, create their own institutional, political and social patterns; this is the task of the government. ${ }^{7}$ Right-wing totalitarianism offers this "responsibility" to the fascist elite. In the first case, power must be handed down to generations - past, present and future -to determine what is good or bad at the societal level. In the second case, the exercise of power becomes an extension of totalitarian ideology and action. Conservative ideology states that people are limited in their rights and freedoms as dictated by history, traditions or customs; under right-wing totalitarian regimes, people lose their rights and

7 Regarding conservative ideology's variations, see E. H. H. Green, Ideologies of Conservatism. Conservative Political Ideas in the Twentieth Century, New York, Oxford University Press, 2002, pp. 3-17. 
liberties as the fascist elite dictates. Conservatism accepts that sometimes power can cause pain and suffering, while the far-right regards the two elements as history constants. If the former ideological trend highlights power's non-violent nature, the latter gives violence a rationalised and institutionalised form.

\section{THE PERVERSION OF DEMOCRATIC AND LIBERAL PRINCIPLES BY RIGHT-WING TOTALITARIANISM}

Generally speaking, the relations of the totalitarian right-wing ideology with liberalism have been organically opposite, but in some cases, they were characterised by temporary cohabitation or collaboration. The opposition between generic fascism and the liberal trend is more visible in the political and economic sphere. It became manifest in the context of the crisis of European democracy in the first decades of the twentieth century. The far-right tried and partially succeeded in undermining the Enlightenment foundations of liberalism: pluralism, tolerance, individualism, rationalism, justice, separation of powers in the state, natural rights, egalitarianism, straightforward progress, freedom, social contractualism, resistance to tyranny, multi-party system, etc.

Pluralism is one of the fundamental features of democratic systems. It is defined, in the broadest sense, as the belief in diversity or multiplicity. Politically, it refers to multipartyism, a multitude of ethical and moral values or a variety of cultural beliefs. As a normative term, pluralism suggests the idea that diversity is healthy and desirable because it defends the principle of individual freedom and contributes to the fair distribution of political power. The unilateral tendency of totalitarianism, the conceptual, ideational and institutional overlap between the state and the single party, the elimination of the system of rights and liberties, the ideology and parasitism of thought due to irrational elements have all destroyed this foundation of liberal Enlightenment democracy. Pluralism offers flexibility, mobility and adaptability, both ideationally, politically, socially, and decisionally, but at the same time, it displays several systemic flaws: uncertainty, ambiguity, instability. Right-wing totalitarian regimes have employed these weaknesses against the liberal model of democracy; thus, they proposed a more straightforward social restructuring logic, mostly, Manichean. Both authoritarian individuals (potential totalitarian leaders) and the massed individuals adopted predefined behavioural frameworks, a simplistic (black-and-white) worldview, and a stereo- 
typed language, ${ }^{8}$ devoid of semantic nuances. The anti-democratic mentality eliminates autonomy of reason, relying on unconditional submission to authority, respect for hierarchy, and a messianic outlook on the world.

Tolerance and diversity. Liberal social ethics is characterised by the will to accept and celebrate political, cultural and moral diversity. Pluralism, or diversity, originates in the principle of individualism and in the assertion that human beings are unique creatures. The preference of liberal thinking for diversity has often been associated with tolerance. The latter presupposes the will to allow people to think, speak, and act in ways that one generally tends to reject. Tolerance is both an ethical ideal and a social principle.

On the one hand, it is a goal of personal autonomy; while, on the other hand, it imposes a set of rules on how people should behave with their peers. The principle of tolerance would have to be extended to all religious, moral or private life issues. Of course, it is very closely linked to the concept of negative freedom. In totalitarian systems, tolerance is destroyed by prejudices, the scapegoat theory, and the permanent conspiracy of internal and external enemies. Diversity becomes impossible in such political regimes because individuals and social groups are forced to replace critical, rational thinking with a mentality steeped in irrationalism (myth, magic elements, taboos, archetypes). Diversity and tolerance thus become the natural enemies of the new utopian vision of the world. They cease to be factors of social cohesion, being swiftly replaced by intolerance. This stands for lack of respect for one's peers' beliefs and practices and does not accept the idea of difference or diversity, underlying racism, ${ }^{9}$ anti-Semitism, xenophobia, etc. It can often lead to generalised, rationalised, and institutionalised violence.

8 J. W. Young, Totalitarian Language: Orwell's Newspeak and Its Nazi and Communist Antecedents, University of Virginia Press, 1991, pp. 23-26; Béatrice Turpin, Victor Klemperer et le langage totalitaire d'hier à aujourd'hui. Compte-rendu du colloque de cerissy-laSalle, în „Hermès”, nr. 58, 3/2010, pp. 63-67; Victor Klemperer, The Language of the Third Reich. LTI - Lingua Tertii Imperii. A Psihologist's Notebook, translated by Martin Brady, Londra-New York, Blomsbury Publishing Plc, 2013, pp. 10-16; Vlad Gafița, Totalitarian Language through the Lens of the Viral-Metamorphic Theory, in „Meridian Critic", no: 1 (volume 30), 2018, pp. 55-62.

${ }^{9}$ About racism, see: Marius Turda, Eugenism şi modernitate. Naţiune, rasă şi biopolitică în Europa (1870-1950) [Eugenics and modernity. Nation, race and biopolitics in Europe (1870-1950)], translation into Romanian by Răzvan Pârâianu, Iași, Polirom Publishing House, 2014; M.A. Livingstone, The Fascists and the Jews of Italy: Mussolini's Race Laws, 1938-1943, New York, Cambridge University Press, 2014; John Rex, Rasă şi etnie [Race and Ethnicity], translation from English into Romanian by Dan Pavelescu, Bucharest, DU Style Publishing House, 1998. 
Individualism represents the belief in the individual's supreme importance in relation to any social group or community. Methodological individualism suggests the formation of society from single autonomous human entities. From an ethical point of view, individualism states that society should be built according to moral norms that protect the person's interests, rights, and needs. The antiliberal reaction of the far-right became manifest in replacing individualism with collectivism (the belief that people's collective effort has more significant practical and moral value than the individual action). The supreme good of the collective entity (nation or race) is invariably situated above the individual good; thus, collective egoism consumes individual selfishness. ${ }^{10}$ People, therefore, become collectivist entities by massification, disintegration, de-individualisation and atomisation. They are integrated or assimilated to the national, state or racial community, losing or surrendering more or less voluntarily their system of liberties and rights.

Freedom is the fundamental political value of liberalism and the unifying principle of this ideology. Initially, it stood for a natural right as well as an essential prerequisite of human existence. Freedom has allowed individuals to pursue their interests and to be able to choose between various solutions. Later, it was regarded as the sole condition by which people can develop their skills and talents or reach their full potential. The abolition of individualism and the adoption of a collectivist and organicist view by the far-right ideology have metamorphosed freedom (in fact, abolished it) into responsibility, obligation and duty. The fascists rejected any form of personal liberty, considering it abstract, universalistic nonsense, utterly disconnected from reality. By contrast, "genuine freedom" means, in its totalitarian sense, obedience to the Will of the Leader and the individual's absorption into the national, racial, and state community. ${ }^{11}$ Freedom of the individual is lost to the will of the community or of the masses.

Rationalism. The libertarian principle is inextricably linked to the belief in reason. Liberalism has been and has remained an integral part of the Enlightenment project. The central theme of the Enlightenment coincided with the desire to release man from the superstition and ignorance "prison", as well as

10 The methodological individualism is analyzed in books as: Lars Udehn, Methodological Individualism. Background, History and Meaning, London-New York, Routledge Taylor \& Francis Group, 2001; Francesco di Iorio, Cognitive Autonomy and Methodological Individualism. The Interpretative Foundations of Social Life, Heidelberg-New YorkDordrecht-London, Springer International Publishing Switzerland, 2015.

11 Will Dudley, Hegel, Nietzsche and Philosophy. Thinking Freedom, Cambridge, Cambridge University Press, 2007, pp. 4-11. 
the opening of the age of reason. The rationalism of the Enlightenment influenced liberalism in many respects. Firstly, it has consolidated confidence in individualism and freedom; secondly, it offered the liberals the rectilinear progress pattern. The liberal trend has implemented this "pattern" by the expansion of knowledge, the scientific revolution and the rejection of dogmatic thinking. Rationalism is linked to the belief that the world displays a rational structure that can be decoded by critical research. As a philosophical theory, it stems from the idea that knowledge derives more from reason than from experience, thus opposing empiricism. As a general principle, rationalism is based on human beings' ability to understand and explain the world, to find solutions to various problems with the help of intellect. Although it does not dictate the ultimate purpose of human behaviour, it indeed suggests ways to reach it.

Irrationalism 12 is a viral-metamorphic form of "infecting" rationalist thinking. Although fascist and fascism-resembling movements were generally born after World War One, they synthesised a pre-existing ideational background dating as early as the end of the nineteenth century. The far-right used irrational ideas and theories circumscribed to the anti-Enlightenment. A series of thinkers began to reveal human reason limits, drawing attention on and emphasising elements such as feelings, instincts and atavistic impulses. Friedrich Nietzsche said that people are motivated by strong emotions, oversizing the role of the will to the detriment of reason, especially the "will of power."13 In his book Reflections on Violence (1908), the French trade unionist Georges Sorel highlighted the importance of political myths and, in particular, the myth of the general strike. He did not view them as passive descriptions of political reality but as expressions of Will, emotions and action. ${ }^{14}$ The intuitionist philosopher Henri Bergson advanced the theory of vitalism, based on the idea that living organisms develop specific features with the help of a universal vital force. ${ }^{15}$ The purpose of human existence is, therefore, to express this particular type of energy.

\footnotetext{
12 Regarding irrationalism, see: William Barret, Irrational Man. A Study in Existential Philosophy, New York, Anchor Books, 1962, pp. 69-78.

${ }^{13}$ See: Henry Hazlitt, The Way to Will-Power, Auburn-Alabama, Ludwig von Mises Institute, 2008; Jean-Etienne Joulié, Will to Power, Nietzsche's Last Idol, London, Palgrave Macmillan, 2013.

${ }^{14}$ George Sorel, Réflexions sur la violence, deuxième édition, Paris, Librairie Des Sciences Politiques et Sociales, 1910, pp. 91-122.

${ }^{15}$ Henri Bergson, L'évolution créatrice, Paris, Les Presses Universitaires de France, 1959, pp. 9-15.
} 
Although anti-rationalism per se is not proto-fascist in character, right-wing totalitarianism has provided a political expression to the most radical forms of anti-Enlightenment thinking. This trend of thought has influenced fascism in many ways. First, it induced a pronounced state of anti-intellectualism, reflected in the tendency to despise abstract thinking and to emphasise the role of action. Intellectual life was devalued by the far right, which mainly concerns feelings, emotions, and instincts. Fascist ideology has a rather weak coherence and rigour, but it has always sought to discover a mythical aura. The great ideologues or leaders (Hitler, Mussolini) were first and foremost propagandists, interested only to a small extent in theories and ideas. They wanted to exercise power through action, as an emotional response to the reaction of the masses. At first sight, generic fascism ( $c f$. R. Griffin) seems to be an anti-philosophy (due to features such as anti-rationalism, anti-Enlightenment, anti-liberalism, anti-conservatism, anticapitalism anti-communism etc.) or a form of nihilism, because it has consistently rejected most of the classical moral and political principles, depicting Western social tradition as a system of perverted values (an upside-down system). In fact, the far-right manifests itself as a viral-metamorphic form of Cartesian rationalism or as an infection of democratic political thinking with Enlightenment origin. This "pathology of modernity" (H. Arendt), in contact with liberalism, has (partially and temporarily) destroyed its conceptual, philosophical and humanistic foundations.

Justice. In democratic regimes, it is based on a particular type of moral judgment built around a reward-punishment system. The idea of social justice refers to the distribution of material and symbolic benefits within the societal space. The liberal theory of law is based on the principle of equality. Thus, through individualism, justice acquires egalitarian grounds (human beings are born equal in that each person has a set of natural rights and liberties, enjoying the same formal status in society). Liberals disapprove of any privilege or advantage based on such elements as gender, race, skin colour, faith, religion or origin. Rights cannot be reserved for a particular person or social class; their distribution being made in keeping with the principle of equality before the law. The political liberal trend also adheres to the idea of equality of chances, relying on the belief in meritocracy. The latter possesses both moral and economic foundations.

Right-wing totalitarianism has destroyed the humanist and liberal foundations of justice. The latter ceased to be one of the three autonomous forces in the state because the principle of separation of powers is nullified or metamorphosed into a formal hypostasis of democracy. Judicial power becomes a mere extension or punitive instrument of the regime, meant to apply rationalised and institutionalised violence. Justice no longer proceeds as a factor in regulating 
social tensions but as an element of control over a closed (cf. K. R. Popper) and massed society. Through ideologisation, judges lose their immovability, being forced to respect, first of all, the immutable principle of the Leader (the Führerprinzip type), and not to deviate from the official line imposed by the stateparty. The relations of the judiciary with the executive power are invariably relations of subordination.

\section{THE SOCIALIST ORIGINS OF RIGHT-WING TOTALITARIANISM}

The far-right can be considered a viral-metamorphic variation of socialism, impregnated by palingenetic populist ultranationalism. Thus, generic fascism or the fascist minimum is not the opposite of socialism, but a mutant form of it. Both Mussolini and Hitler portrayed their ideas as particular hypostases of socialism. The former had been an influential member of the Italian Socialist Party and the editor-in-chief of the official gazette "Avanti". The latter conferred German socialism a paradoxical (ultranationalist) characteristic. The initial causality of this attitude was, of course, linked to the cynical and pragmatic attempt to obtain the electoral support of the industrial proletariat.

However, despite the formal ideological rivalry between fascism and socialism, followers of the interwar far-right displayed apparent affinities to specific ideas and socialism positions. The lower strata of the middle class frequently expressed their disgust for capitalism and, above all, for the industrial, financial and banking big bourgeoisie. The leftist roots of some satellite organisations of NSDAP (Nationalsozialistische Deutsche Arbeiterpartei, the Nazi Party), such as the Storm Troopers (SA, Sturmabteilung) were more than transparent (the social structure of most members). Like socialism, the far-right adhered without reserve to collectivism, anarcho-syndicalism - at least in its incipient phase, until they came into power -openly opposing the "bourgeois" value system. Often, the Nazis "trumpeted" slogans such as "The Common Good before the Private Good". The partisans of the far-right despised "bourgeois materialism" considering that the desire to get rich must be subordinated to the idealist vision of national regeneration ${ }^{16}$ and the creation of a new utopian order (Weltanschauung). Fascist and regimes resembling fascism have often practised a socialist economic style to regulate or control the liberal economic system (for

\footnotetext{
${ }^{16}$ See Zeev Sternhell, Mario Sznajder, The Birth of Fascist Ideology, New Jersey, Princeton University Press, 1994; Emilio Gentile, Robert L. Miller, The Origins of Fascist Ideology, 1918 - 1925, New York, Enigma, 2005.
} 
example, economic planning, exacerbated statism, corporatism, autarchy etc.). When not replaced by the corporate model (applied in Mussolini's Italy, Franco's Spain, or Salazar's Portugal), economic liberalism was subordinated to totalitarian ideological objectives (for example, after 1939, H. Göring reorganised German capitalist economy under the title Four-Year Plan, inspired, of course, by USSR's five-year plans). However, the notion of "fascist socialism" has some clear limitations: leftist elements within the right-wing extremist movements (the SA troops in Germany, the Sorelian syndicalists in Italy) were quickly marginalised after taking power, in hopes of attracting the "big finance" support.

Most of the time, the fascist ideas of organising economic life were vague and inconsistent. In many cases, pragmatism was more important than ideology. The revolution predicted by the far-right was not a social revolution, but rather a revolution of the psyche (individually and collectively) or the spirit, aimed at creating a new type of human being (always understood in masculine terms). The New Man or the fascist man had to be a hero, motivated by honour, duty and selfsacrifice, ready to "dissolve" his personality into the collectivist entity 17 (Community/ Nation/ Race). Finally, we notice the prominence of the anticommunist attitude within the fascist or movements resembling fascism in relation to anti-capitalism. One of these organisations and parties' primary objectives was to remove the proletariat from the "ideological umbrella" of Marxism and Bolshevism, but also to replace the class struggle with an integral and holistic vision of the nation, state, and race.

\section{SCIENTIFIC COMMUNISM AND GENERIC FASCISM MIRRORING}

The two forms of totalitarianism (left and right) can be regarded as distorted mirrors of democracy. Both are collectivist, reactive and viral-metamorphic forms - anti-Enlightenment and anti-liberal. Communism remains universalist, a utopia, while generic fascism stands out in its denial of universalism, managing to assume only dystopian forms. The two ideologies can only exist under dictatorial, nonpluralistic and one-party regimes. Both show a tendency to One (unifying): the communist ideology proposes the creation of a classless society (in fact, the existence of a single class - the proletariat), while the far-right rallies to the idea of a closed, super-hierarchical and monolithic society (the syncretic synthesis between Nation-State-Race). Communism has generally been characterised by

17 Dan-Ioan Dascălu, Personalitatea totalitară [Totalitarian Personality], Bucharest, Didactic and Pedagogical Publishing House, 2002, p. 89. 
ideological expansionism, whereas fascism, Nazism, and fascism-resembling variations by militarist expansionism. Although both are viral-metamorphic or polymorphic mutant entities, we must recall that the far left is a trans- and postmodern phenomenon, while the far-right maintains its anti-modernity.

The philosophical origins of communism are medieval, if reference is made to the work of the English Catholic thinker Thomas More, suggestively entitled Utopia (1516). In the modern age, this political trend is associated, of course, with the work of Marx and Engels - The Communist Manifesto (1848). The two thinkers proposed a system in which the property is jointly owned by an atheistic society devoid of social classes, thus eliminating the differences between labourers and the privileged classes (the bourgeoisie). They supported the creation of a state that would eliminate all societal problems caused by inequality and exploitation, guiding humankind to the highest levels of progress. However, Marx and Engels did not describe the practical ways of achieving their utopian vision. ${ }^{18}$

The far-right was based on the deification and glorification of the nation. Its origins can be found in the nineteenth-century nationalist movements. French thinkers Charles Maurras and Georges Sorel theorised integral nationalism, namely the radical anarcho-syndicalist action, suggesting the creation of an organicist model of society. Fascist and fascism-resembling movements were formed in different ways for each country, managing to assert themselves in Italy, Germany, Spain, Portugal, or failing to accede to power in France or the United Kingdom.

Despite its polymorphic hypostases, the interwar far-right shared a series of common "values": militarist and expansionist ultranationalism; opposition to parliamentary democracy; conduct of conservative and autarchic economic policies; faith in a natural social hierarchy and the domination of elites; the desire to create an organic national community in which the interests of individuals are subordinated to the "general good of the nation", and the synthesis between propaganda and the will of the people. ${ }^{19}$ As far as the social structure and hierarchy

18 Regarding the analysis of Marxist-Leninist view in western historiography, see: J. A. Jordan, The Evolution of dialectical Materialism: A Philosophical and Sociological Analysis, London, Macmillan, 1967; David Mc Lellan, Marxism after Marx, London, Macmillan, 1980; Jorge Larrain, Marxism and Ideology, London-Basingstoke, The Macmillan Press Ltd., 1983.

19 Integral nationalism was represented in France by Action Française, a proto-fascist organization, and in Portugal by lusitan integralism sustained by Salazar's regime; see: Michel Leymarie, Jacques Prévotat (eds.), L'Action Française. Culture, société, politique, Villeneuve d'Ascq, Presses universitaires du Septentrion, 2008 ; Diamantino P. Machado, 
are concerned, the Communists proposed the abolition of all hierarchical forms of organisation of society by imposing state control on private property and industry. In opposition to the classless society's Marxist concept, generic fascism supported the development of a strict, closed and self-sufficient class structure, making sure that each individual has a predetermined, specific, and unchangeable role. For example, women's role in the totalitarian right-wing society was limited to domestic and family life, which can be explained by its high degree of masculinisation. Both the far right and the far left opposed the process of democratisation, but with some differences. Some leaders, such as Hitler and Mussolini, had participated in elections before they came to power, but after taking office, they opposed universal suffrage, becoming dictators for life. The Communists used democracy as a way of gaining access to the government but ultimately destroyed the multi-party system, replacing it with the quasi-total domination of the single party.

At the economic level, the far left is based on the equal distribution of wealth, with members of society receiving the same share of the benefits from labour or production. To ensure that economic equality is respected, all means of production are owned and controlled by the state. By planning, the latter coordinates all decisions concerning investment, production, or allocation of resources. The far-right allows the existence of the private property, but its economic system is put, almost exclusively, in the service of consolidating and glorifying the state. Both fascist Italy and Nazi Germany set self-sufficiency as their fundamental economic goal so that each of these states could survive without commercial exchanges with other states.

Both forms of totalitarianism undermined or destroyed individual rights. In the case of communism, religion and private property were eliminated, with the government controlling or limiting freedom of choice in both education and labour. As far as the outlook on war is concerned, the communists considered it right for the economy but stated that, in general, it should be avoided. The farright followers regarded it as a positive element, both for strengthening individual character, the nation's moral development, and the good of the state. ${ }^{20}$ The worldview of communism is based on its nature as an international movement, the

The Structure of Portuguese Society. The Failure of Fascism, Westport-Connecticut, Praeger Publishers, 1991.

${ }^{20}$ A very interesting comparison between left wing and right-wing totalitarianism is made by Stanley G. Payne, Fascism and Communism, in "Totalitarian Movements and Political Religions", I, 2000, No. 3, pp. 1-15. 
ideological solidarity of the communist parties in various countries, and the rejection of capitalism or distrust of nationalist leaders and peoples. Fascist or fascism-resembling regimes are invariably ultranationalist, identifying only with similar state and political systems. They reject a priori the idea of internationalism as well as the concept of international democratic legislation. In theory, the Communist society rejects the notion of statehood, social classes, since the government is provided directly by the people.

Although most of the key concepts of the two ideologies and political systems differ, there are several significant similarities: centralised government, planned economy, opposition to the model of liberal democracy, antiindividualism, projection of the new man, collectivism, massification, cult of personality, ideologization and politicisation of all social spheres, destruction of pluralist civil society, monopartism, etc.

\section{TOTALITARIANISM AS A VIRAL-METAMORPHIC MUTATION OF DEMOCRACY}

Along with modernity, democracy becomes an abstract, universalist concept, away from concrete political, social, and economic reality. Since its creation, the term has been restrictive, referring to a particular social, political or economic category. Democracy, as a form of the political organisation of society, proclaims the principle of power held by the people and takes several historical forms: slave democracy (the citizens from Greek poleis and Roman cities, according to Marxist terminology); bourgeois or liberal democracy (a format specific to capitalism that seeks to secure freedom and equality of citizens before law); popular democracy (a paradoxical expression specific to Marxist terminology); internal party democracy (an organisational principle of the Communist Party according to which all members hold the right to participate in solving the problems of the political entity effectively).

The semantic and conceptual opposition between democracy and totalitarianism is apparent because, in reality, only the attitude towards politics and the manner of exercising power differ. The liberal approach considers that politics is a matter of judgment or error, recognising human action's spontaneity and autonomy. Totalitarian thinking is based on the assumption that there is only one truth in politics that takes the form of messianism, postulating a harmonious and perfect scheme of social space. Totalitarianism ultimately recognises a single plane of existence, the political plane, but metamorphosed into a pseudo-religion. 
Both schools of thinking, the democratic-liberal and the totalitarian refer to the supreme value of freedom, but differently. While pluralist systems seek and find the essence of liberty in spontaneity and the absence of coercion, nonpluralist regimes consider that freedom can exist only in the pursuit and attainment of some absolutized collective goals.

Liberal Democrats say that through individual freedom an idealised state of harmony can be achieved. At the same time, totalitarianism followers view the state of freedom as a challenge for action or as the result of an upcoming event. The so-called "totalitarian democracy" is placed under the sign of the "paradox of freedom". ${ }^{21}$ It is related to the question: is human freedom compatible with an exclusive social existence model, even if this way of thinking ultimately aims at social justice and security?

The answer cannot be definitive if reason and will do not always guarantee freedom. That is why the extreme forms of the sovereignty of the people become subordinate to objectives that are often more transcendent than concrete. The particular problems and antinomies of "totalitarian democracy" result from the difficulty reconciling the ideas of freedom and definite purpose. This problem can only be solved if we regard the human being not as he/she is, but as he/she will be.

Totalitarian political messianism is often considered to have its origins in the eighteenth century, with the emergence of the "schism" between traditional religion and democratic secular religiosity. Both forms of democracy are found in the phenomena and processes specific to the emergence of modernity. With the French Revolution, a real decline of traditional order in Europe occurred: Christianity began to lose its intellectual and emotional control over society; the highly hierarchical feudalism began to disintegrate under the impact of social and economic factors; the old concept of a status-based community was replaced by the idea of an abstract, individualised and universalised human being.

The decline of religious authority involved the liberation of human conscience and the replacement of the ethics subordinated to religion with a form of secular morality. The rejection of the values of transcendent justice of the Church has imposed that the state remained the only form of improvement and sanction of morality. Politics begins to be considered as inseparable from ethics. The decline of the social status idea coincided with the rise of liberal individualism, the rejection of privileges. This process also involves some totalitarian potential. Thus, although empiricism is the ally of freedom, and the doctrinal spirit is the

21 J. L. Talmon, Origins of Totalitarian Democracy, London, Secker \& Warburg, 1952, p. 2. 
"friend of totalitarianism", the idea of a man regarded as an abstraction, independent of the historical context to which he belongs, would later become a powerful "vehicle for totalitarianism".

The eighteenth-century has never clearly distinguished the difference between the person's right to expression and the person's right to social action. Freedom Enlightenment theorists have regularly referred to the human attribute called virtue. It was to become one of the essential foundations of social harmony. However, the Enlightenment thinkers did not offer a coherent explanation for the inevitable conflict between freedom and virtue. When the secular religion of the eighteenth century (democracy) had to resolve this conflict, a new schism of the modern political world emerged. Thus, liberal democracy chose to move away from the spectrum of force, promoting a philosophy based on the trial-error pattern. At the same time, totalitarian messianism developed a doctrine based on the right of domination and coercion against those who refused to be "free and virtuous" (reference is made to the radical forms of the French revolution such as the Jacobin terror).

Another cause for the schism was the property issue. The democratic-liberal vision of it was dominated by the economic side, while the totalitarian political messianism was rather ethical and political. There were some exceptions in the eighteenth century: the case of the physiocrats who combined absolutism in politics with the economic theory of laissez-faire.

The modern so-called "totalitarian democracy" was, in fact, a dictatorship based on widespread enthusiasm, utterly different from the absolute power based on the divine right of the monarch. This dictatorial form revolved around a pseudo-democratic ideology of the masses, expression of a paradoxical and contradictory synthesis between the idea of natural order and the exercise of the right to self-expression advocated by J. J. Rousseau. ${ }^{22}$ Often the concept of a common will promoted by the Enlightenment is ambiguous, a priori, combining the immanence of man's Will, unanimity, strength, or contradictions and antinomies that cannot be resolved in the real world.

The confusion between majority and consensus appears both in pluralisticdemocratic regimes and in authoritarian and totalitarian regimes. ${ }^{23}$ In the former

22 See John T. Scott (ed.), The Major Political Writings of Jean-Jacques Rousseau. The Two Discourses and the Social Contract, Chicago-London, The University of Chicago Press, 2012, pp. 60-77.

${ }^{23}$ On the nuanced differences between democratic, authoritarian and totalitarian systems, see: Giovanni Sartori, Parties and Party Systems. A Framework for Analysis, Cambridge, 
case, it manifests itself as a tendency to stabilise existing tensions in the social and political environment. The relative or absolute majorities obtained by parties in the elections induce the necessity for negotiation or compromise in the "power game" to reach a consensus. The latter is a form of legitimising the winners, securing the continuity of the democratic regime. In authoritarian or semitotalitarian systems, a consensus is often the result of force or coercion imposed by the Leader or the oligarchic circles of power on the population. In this case, there is a certain pseudo-legitimation resulting from a revolution, coup d'état, or the election of a relative majority. Left and right-wing forms of totalitarianism assert the idea of consensus through the perverted language of propaganda, overlapping the Leader's Will with the ideological will of the proletariat, nation, race, or state.

The elitist character of the notion stands out since the appearance of the concept in antiquity. The demos of ancient Greece was a tiny category of citizens (males of legal age), excluding barbarians (foreigners), slaves, women and, of course, children. Political liberties, privileges and responsibilities belonged only to this category; thus, the current meaning of democratic freedom would never have applied to the world of Greek poleis. Rome took over the Hellenic model and transformed it while bringing some improvements to the law system. The extremely low number of Roman citizens during the Republic and the Empire meant that a multitude of social, ethnic, and racial categories did not benefit from the rights and liberties of Roman civilisation. Starting with the third century AD, the extension of the right to citizenship to all Latin inhabitants throughout the empire and among some barbarians led to the decline of the Western Roman Empire in the fifth century. The so-called "Roman democracy" was an illusion just as Pax Romana represented only a consequence of militarist policies and new territories and peoples' conquest. In the Middle Ages, democracy was masked ideationally through some thinkers' utopian prospects, and with the Renaissance, it took the form of humanism. Thus, the man was partially restored, starting to compete with the divinity.

Starting with modernity, democracy has become an abstract, universalist concept, moving gradually away from realities and the concrete historical context.

Cambridge University Press, 1976; Giovanni Sartori, Giacomo Sani, Polarization, Fragmentation and Competition in Western Democracies, in Hans Daalder, Peter Mair (eds), Western European Party Systems: Continuity and Change, Beverly Hills, Publishing House Sage, 1983; Robert A. Dahl, Despre democraţie [About Democracy], Iași, European Institute Publishing House, 2003. 
The transfer of sovereignty from the monarch to the people through the social contract eliminated the divine character of power in the process, desacralizing it and making it immanent. Although democracy was intended as a substitute for religion with the Modern Age, its path remained incomplete. Its limit was represented by man or society; therefore, its religious character is rather insubstantial. Totalitarianism does not deal with the human being as an individual entity, but as a collective or collectivist form of man; in comparison with liberal democracy, totalitarian forms of thinking aim to transcend humanity's limits. It also aims at a "re-sacralisation of the individual" or some human groups (proletariat, race, people, nation). The radicalisation of democracy does not improve it. Still, it transforms it into tyranny, while the exacerbation of freedom and equality within a community leads to a reduction in its members' importance and role. Often, authoritarian, despotic and dictatorial forms of power require legitimacy from the people and claim to act on behalf of the people to solve a particular crisis. As a matter of principle, dictatorships have emerged as provisory ways of stabilising and re-harmonising society. However, absolute power cannot be controlled primarily by those who exercise it, as it creates a psychological corruption in their minds, which, after all, is human in nature.

The positive character of democracy is, in fact, a deception, an illusion, since totalitarian regimes also assert their origins in the democratic model (relating to the people, working through the people and for the people). Democratic relativism is transferred to totalitarian forms of leadership through the semantic ambiguity of the term people, as well: Who are the people? What are the limits of its action? Why would people hold the absolute good or truth?

There is often a numerical confusion, a social confusion, or a confusion between the relative and the people's absolute character regarding the concept mentioned above. The modern notion of democracy is based on a preconceived idea - that it is always supposed to be fair, righteous, progressive, etc. However, history often contradicts democratic positivism, which is revealed to us as selfsufficient, closed, ossified, etc. We also observe a certain monopolisation of the truth by democracy. Still, the latter cannot become a religion because of its the lack of transcendence (as already mentioned, its limitation is the man himself since any religion worships supernatural forces that overcome, dominate and rule over the human being). Totalitarian regimes are critically accountable to the set of natural rights and freedoms: they either deny them by antinomic positioning or turn them into perverted elements that bear no connection with the original. Thus, the general Enlightenment and democratic will are transformed in contact with totalitarian thought into the will of power of mass groups or communities. 
Individual freedom is diluted within the totalitarian collectivist entity, turning into obedience, absolute loyalty, and spirit of sacrifice.

In totalitarianism (especially the right-wing one), egalitarian principles become hierarchical forms based on pyramidal inequality aesthetics. The Man undergoes an anthropological revolution by acquiring the appellation of 'new' (metamorphosing into an entity lacking morality, consciousness, critical reason, and personality). Democracy is based on two postulates: 1) through democracy, the people discover good naturally; 2) by definition, anything people want or do is right. Therefore, the people create good; in other words, through the voice of the people, the voice of God is heard (Vox Dei, Vox Populi). Also, the voice of the people must be listened to as the voice of God, that is, the people is God (Vox Populi, Vox Dei). These democratic postulates are reduced by totalitarianism to a single "legitimacy": the Leader is one and the same with the people, thus being mistaken for the divinity. Through totalitarianism, democracy succeeds in becoming a "religion". It can be said that the democratic idea is a legal fiction, according to which the majority simultaneously holds the force - the justice the wisdom - the truth.

Democracy contains in itself, a priori, totalitarianism. Monarchies, oligarchies, aristocratic regimes have not directly turned into totalitarian forms. They were compelled to go through the transitional phase of democracy. Unfortunately, the latter is based on the number of voters and not on their quality (the "dictatorship of the majority"). Thus, its character resurfaces as restrictive, closed and univocal. The relationship between the two notions is often inversely proportional. Absolute equality can only be achieved by suppressing freedom. Also, the radicalisation of freedom induces either inequality or anarchy. Thus, not all democracies are revolutionary, and not all revolutions are democratic.

Although it is claimed that sudden changes in society, economy, or politics have, as a matter of principle, the people's support, they are in most cases the result of the thinking of elites who impose new or original directions. The "intelligence" of the masses, inferior to most individual ones that constitute the collectivities, cannot emit or create ideas, or concepts with a high degree of abstraction. Even in the case of the left, socialist or communist, it was the intellectual elites who devised the models of society's revolutionary transformation. In the natural world, minorities that is, predators - dominate, not majorities or herds. The transfer into the democratic language of a liberal or socialist the idea of natural law has no cover even in the real world, be it of nature or society. It manifests itself through the absence of a hierarchical organisation (it is more likely to encounter this structuring mode in traditionalist societies, based on conservative principles as well as on the idea of 
evolution, and not of revolution). In fact, democracy never really worked. The Athenian form was based on slavery, and the modern forms of liberal or socialist orientation are nothing more than oligarchies or masked bureaucracies. In an authoritarian regime, we must obey the state authority, but we can have freedom of conscience. In a totalitarian system, we must think the same way the administration does, but in an absolutized democracy, we can only think the way the legal authority thinks. This is the reason why ideas such as obedience or disobedience become obsolete and outmoded.

The ethics of pluralistic systems is relatively thin. It displays a certain degree of intolerance because it does not accept a regime other than the democratic one. Totalitarianism is a result of the crisis of democracy, using its imperfections to create mutant forms. Relying on a negationist ideological approach, it destroyed previous paradigms of thought (liberal, socialist) or transformed them by integrating revolutionary or reactionary attitudes (as is the case with conservatism). Sometimes it uses techniques specific to liberal democracy (elections, referendums, but for a limited time and with the hidden (masked) objective of total takeover of power and destruction of the system from within. Both the far-left and the far-right consider themselves stages of evolution, clearly superior to previous ideological and political forms (liberalism, socialdemocracy, conservatism, socialism). In fact, totalitarian systems planned and partially succeeded in perverting democracy by inserting a particular ideology termed viral-metamorphic.

The far-right separates itself from conventional political thinking by radically rejecting egalitarianism. Hence, it is profoundly elitist and patriarchal, based on the belief that an elite and leadership with absolute powers are both natural and desirable. Human beings are born with different abilities and characteristics, which leads to the conclusion that some people are destined to govern, while others are destined to follow and obey. Followers of right-wing extremist movements and parties believed that society is generally made up of three categories of people: the first and the most important class is that of future leaders, whose authority cannot be challenged. The second is the exclusively male "warrior" elite (militarist or militarised), which, unlike the national elites, is distinguished by heroism, vision, and self-sacrifice capacity.

At first glance, fascist elitism ${ }^{24}$ does not differ much from the conservative

${ }^{24}$ António Costa Pinto, Introduction: Political Elites and Decision-Making in Fascist-Era Dictatorships, in idem (ed.), Ruling Elites and Decision-Making in Fascist-Era Dictatorships, New York, Columbia University Press, 2009, pp. XV - XX. 
version of this trans-ideology. In reality, however, there are significant differences. Thus, conservative elites are a consequence of a long and natural evolution of society. They can easily fit into a democratic and pluralist regime, contributing to the economic, intellectual and scientific progress of the world in which they live. They also guide their ideas and actions according to rational principles and, on rare occasions, ideological criteria. Instead, the elites in right-wing totalitarian regimes result from actions with revolutionary implications, aimed at transforming the state, society, economy and human beings into mutant viral-metamorphic or polymorphic entities. In the Third Reich, the prototype of the elite was represented by the SS, whose members have initially been Hitler's bodyguards, and later became a genuine "state within the state". Nazi protection troops stood above the law between 1933 and 1945, being accountable only to the Führer. The third category of people was the masses, seen as weak, inert and ignorant; their destiny revolved around the idea of obedience. Such a pessimistic view of ordinary people's capacities has placed generic fascism in opposition to the concepts of liberal democracy. In any case, the idea of an absolute and quasi/pseudo-divine form of leadership appears to us today as an inverted (perverted) form of the democratic model of government. The fascist or fascism-resembling approach to leadership was influenced by Nietzsche's Superman (Übermensch) concept - that is, a person endowed with extraordinary qualities, superior power and Will. In the book Thus Spoke Zarathustra (1885), Nietzsche portrayed the Superman as a person capable of rising above the "herd instinct" and ordinary (conventional) morality, and who lives only according to his own will. The most influential leaders of the far-right took the titles of Il Duce, Führer, Caudillo, Captain, etc., to detach themselves and emancipate from any form of legal or constitutional government. This way, the concept of legal power was turned into an expression of charismatic totalitarian authority that emanates from the Great Leader himself.

While legal-rational authority (in Weber's terms) operates within a set of laws and rules, charismatic power is potentially boundless. Given that the totalitarian Leader was portrayed as an individual with unique and supernatural qualities, his authority must therefore be absolute. For example, at the massive demonstrations in Nuremberg, the Führer's followers exclaimed: "Adolf Hitler is Germany, and Germany is Adolf Hitler" ("Die Partei ist Hitler. Hitler aber ist Deutschland, die Deutschland Hitler ist" - proclaimed Rudolf Hess). The Italian fascists incessantly repeated that "Mussolini is always right" ("Mussolini ha sempre ragione!"). The Leader's principle (Führerprinzip) means that the whole authority derives directly and unequivocally from the Leader. The intermedia institutions (parliament, parties, free election system) were either abolished or 
weakened to prevent any challenge to or distortion of the will of the totalitarian head of state. The principle mentioned above was rooted in the belief that he possesses the monopoly on ideological truth.

\section{FINDINGS}

The idea of authority has different perspectives according to the criterion of ideology: Liberals believed that power manifests itself "from bottom to top" with the governed's consent. Therefore, it stands for an ontological requirement, having a rational, objective and limited character, constituting a legal-rational scale between the public and the private space. Conservatives believed that authority stems from a natural necessity, exercised "from top to bottom", by virtue of the unequal distribution of experience, wisdom and social position. Authority is as beneficial as it is necessary because it commands respect, loyalty and promotes social cohesion. Usually, socialists were suspicious of the idea of authority, which they regarded as a symbol of oppression, connected to the interests of the powerful and privileged. However, societies built upon socialist principles are based on and respect the collectivity's authority, which they use as a counterweight to individualism and greed. Anarchists regarded all forms of power as destructive and useless, assimilating them with oppression and exploitation. Fascists regarded authority as a manifestation of personal or charismatic leadership that emerged among individuals with unique and exceptional qualities. Such power can only be absolute and incontestable, becoming implicitly or explicitly total or totalitarian. The far-right ideology often overlaps with the concepts of authority and power. Suppose liberalism, socialism, and communism have desacralized power. In that case, fascism seeks to resacralise it, transforming its ideology into a political religion and the Leader into a quasi-divine entity of immanent nature. The totalitarian form of power displays several distinct features: reactive character and opposition to liberal democracy, socialism and communism; glorification of primary emotions, feelings and instincts; anti-intellectualism, the appeal to Will and intuition, considered driving forces of human actions; contempt for democratic pluralism (seen as a source of the decadence of modern society) and parliamentarism (seen by the ideologues of totalitarianism as useless, empty speech); blurring or abolition of the principle of power separation within the state; replacement of egalitarianism with the principle of hierarchy and inequality, and promotion of elitism in all areas of public life; fetishization of the concept of individual freedom and its replacement with collective responsibility. 
New approaches to developing the viral-metamorphic theory must be explored in the future by delving deeper into its implications. And, first of all, further investigation into the difference between "classic" right-wing totalitarianism (Italian fascism and German Nazism) and the fascism-resembling regimes in Spain, Portugal, Romania etc. deserves a thorough analysis.

\section{BIBLIOGRAPHY}

1. Barret, William, Irrational Man. A Study in Existential Philosophy, New York, Anchor Books, 1962.

2. Bergson, Henri, L'évolution créatrice, Paris, Les Presses Universitaires de France, 1959.

3. Bobbio, Norberto, Stânga şi dreapta [Left and Right], Bucharest, Humanitas Publishing House, 1999.

4. Bocancea, Sorin, Conservatorismul [Conservatism], in Huzum, Eugen (coord.), Teorii politice și ideologii [Political theories and ideologies], Iași European Institute Publishing House, 2013.

5. Carpinschi, Anton, Conservatorismul, doctrină a autorităţii şi restauraţiei [Conservatism, the doctrine of authority and restoration], in Mungiu-Pippidi, Alina (coord.), Doctrine politice contemporane. Tipologii, dinamică, perspective [Contemporary political doctrines. Typologies, dynamics, perspectives] Iaşi, Moldova Publishing House, 1992.

6. Compagnon, Antoine, Antimodernii. De la Joseph de Maistre la Roland Barthes [Anti-moderns. From Joseph de Maistre to Roland Barthes], translation from French by Irina Mavrodin and Adina Dinițoiu, Bucharest, Art Publishing House, 2008.

7. Dahl, Robert A., Despre democraţie [About democracy], Iași, European Institute Publishing House, 2003.

8. Dascălu, Dan-Ioan, Personalitatea totalitară [Totalitarian Personality], Bucharest, Didactic and Pedagogical Publishing House, 2002.

9. De Maistre, Joseph, Istorie şi providenţă [History and Providence], Bucharest, Anastasia Publishing House, 1997.

10. Di Iorio, Francesco, Cognitive Autonomy and Methodological Individualism. The Interpretative Foundations of Social Life, Heidelberg-New York- Dordrecht-London, Springer International Publishing Switzerland, 2015.

11. Dudley, Will, Hegel, Nietzsche and Philosophy. Thinking Freedom, Cambridge, Cambridge University Press, 2007.

12. Eagleton, Terry, Ideology: An Introduction, Londra-New York, Versus, 1991.

13. Gafița, Vlad, Totalitarian Language through the Lens of the Viral-Metamorphic Theory, in "Meridian Critic", no: 1 (volume 30), 2018.

14. Gentile, Emilio; Miller, Robert L., The Origins of Fascist Ideology, 1918 - 1925, New York, Enigma, 2005. 
15. Germino, Dante, Preliminary Reflections on the Open Society: Bergson, Popper, Voegelin, in Germino, Dante; Von Beyme, Klaus (eds.), The Open Society in Theory and Practice, Haga, Martinus Nijhoff, 1974.

16. Green, E. H. H., Ideologies of Conservatism. Conservative Political Ideas in the Twentieth Century, New York, Oxford University Press, 2002.

17. Hazlitt, Henry, The Way to Will-Power, Auburn-Alabama, Ludwig von Mises Institute, 2008;

18. Iliescu, Adrian-Paul, Conservatorismul [Conservatism], in Mungiu-Pippidi, Alina (coord.), Doctrine politice contemporane. Tipologii, dinamică, perspective [Contemporary political doctrines. Typologies, dynamics, perspectives], Iaşi, Moldova Publishing House, 1992.

19. Iliescu, Adrian-Paul, Conservatorismul anglo-saxon [Anglo-Saxon Conservatism], Bucharest, All Publishing House, 1994.

20. Jordan, J. A., The Evolution of dialectical Materialism: A Philosophical and Sociological Analysis, London, Macmillan, 1967.

21. Joulié, Jean-Etienne, Will to Power, Nietzsche's Last Idol, London, Palgrave Macmillan, 2013.

22. Kirk, Russel, The Conservative Mind: From Burke to Eliot, Revised Edition, Chicago, Henry Regnery Company, 1960.

23. Klemperer, Victor, The Language of the Third Reich. LTI - Lingua Tertii Imperii. A Psihologist's Notebook, translated by Martin Brady, London-New York, Blomsbury Publishing Plc, 2013.

24. Larrain, Jorge, Marxism and Ideology, London-Basingstoke, The Macmillan Press Ltd., 1983.

25. Leymarie, Michel; Prévotat, Jacques (eds.), L'Action Française. Culture, société, politique, Villeneuve d'Ascq, Presses universitaires du Septentrion, 2008.

26. Livingstone, M.A., The Fascists and the Jews of Italy: Mussolini's Race Laws, 19381943, New York, Cambridge University Press, 2014.

27. Machado, Diamantino P., The Structure of Portuguese Society. The Failure of Fascism, Westport-Connecticut, Praeger Publishers, 1991.

28. Mc Lellan, David, Marxism after Marx, London, Macmillan, 1980;

29. Nisbet, Robert, Conservatorismul [Conservatism] Bucharest, Du Style Publishing House, 1998.

30. O'Sullivan, Noel, Conservatorismul [Conservatism], in Enciclopedia Blackwell a gândirii politice [The Blackwell Encyclopaedia of Political Thought], Bucharest, Humanitas Publishing House, 2000.

31. Payne, Stanley G., Fascism and Communism, in "Totalitarian Movements and Political Religions", I, 2000, No. 3, pp. 1-15.

32. Pinto, António Costa, Introduction: Political Elites and Decision-Making in FascistEra Dictatorships, in idem (ed.), Ruling Elites and Decision-Making in Fascist-Era Dictatorships, New York, Columbia University Press, 2009. 
33. Popper, K. R., Societatea deschisă şi duşmanii ei [The Open Society and Its Enemies,] vol. I, Vraja lui Platon [The Spell of Plato], translated into Romanian by D. Stoianovici, Bucharest, Humanitas Publishing House, 2005.

34. Rex, John, Rasă şi etnie [Race and Ethnicity], translation from English into Romanian by Dan Pavelescu, Bucharest, DU Style Publishing House, 1998.

35. Șandru, Daniel, Reinventarea ideologiei. O abordare teoretico-politică [Reinventing ideology. A Theoretical-political Approach], Iași, European Institute, 2009.

36. Sartori, Giovanni, Parties and Party Systems. A Framework for Analysis, Cambridge, Cambridge University Press, 1976.

37. Sartori, Giovanni; Sani, Giacomo, Polarization, Fragmentation and Competition in Western Democracies, in Daalder, Hans; Mair, Peter (eds), Western European Party Systems: Continuity and Change, Beverly Hills, Publishing House Sage, 1983.

38. Scott, John T., (ed.), The Major Political Writings of Jean-Jacques Rousseau. The Two Discourses and the Social Contract, Chicago-London, The University of Chicago Press, 2012.

39. Seiler, Daniel Louis, Partidele politice din Europa [Political parties in Europe], Iași, European Institute Publishing House, 1999.

40. Sorel, George, Réflexions sur la violence, deuxième édition, Paris, Librairie Des Sciences Politiques et Sociales, 1910.

41. Sternhell, Zeev; Sznajder, Mario, The Birth of Fascist Ideology, New Jersey, Princeton University Press, 1994.

42. Talmon, J. L., Origins of Totalitarian Democracy, London, Secker \& Warburg, 1952.

43. Turda, Marius, Eugenism şi modernitate. Naţiune, rasă şi biopolitică în Europa (1870-1950) [Eugenics and modernity. Nation, race and biopolitics in Europe (18701950)], translation into Romanian by Răzvan Pârâianu, Iași, Polirom Publishing House, 2014.

44. Turpin, Béatrice, Victor Klemperer et le langage totalitaire d'hier à aujourd'hui. Compte-rendu du colloque de cerissy-la-Salle, in „Hermès”, nr. 58, 3/2010.

45. Udehn, Lars, Methodological Individualism. Background, History and Meaning, London-New York, Routledge Taylor \& Francis Group, 2001.

46. Van Dijk, Teun A., Ideology. A Multidisciplinary Approach, Londra - Thousand Oaks - New Delhi, SAGE Publications, 1998.

47. Voegelin, Eric, Order and History, vol. II, The World of the Polis, Baton Rouge, Louisiana State University Press, 1957.

48. Woods, Roger, The Conservative Revolution in the Weimar Republic, London, Macmillan Press Ltd., 1996.

49. Young, J. W., Totalitarian Language: Orwell's Newspeak and Its Nazi and Communist Antecedents, University of Virginia Press, 1991.

50. Zodian, Mihai, Conservatorismul [Conservatism], in Miroiu, Mihaela (coord.), Ideologii politice actuale. Semnificații, evoluții, și impact [Current political ideologies. Meanings, evolutions and impact], Iași, Polirom Publishing House, 2012. 